\title{
Effect of marine algae supplementation on the fatty acid profile of milk of dairy goats kept indoor and on pasture
}

\author{
F. Pajor, I. Egerszegi, O. Steiber, Á. Bodnár ${ }^{1}$ and P. Póti \\ Szent István University, Faculty of Agricultural and Environmental Sciences, Institute of Animal Husbandry Sciences, Páter \\ Károly 1, H-2100 Gödöllö, Hungary
}

KEY WORDS: fatty acids, goat milk, marine algae, Schizochytrium limacinum

Received: 14 September 2018

Revised: 28 February 2019

Accepted: $\quad 18$ June 2019

${ }^{1}$ Corresponding author:

e-mail: bodnar.akos@mkk.szie.hu

\begin{abstract}
The aim of the study was to investigate the effect of the Schizochytrium limacinum marine algae on the fatty acid profile of goat milk, with particular reference to $n-3$ fatty acids, especially docosahexaenoic acid (DHA) and rumenic acid. Forty dairy goats were randomly allocated to four groups: $\mathrm{C}$ - fed with $1500 \mathrm{~g}$ alfalfa hay and $600 \mathrm{~g}$ concentrate; CMA - received the same forages and concentrate supplemented with $15 \mathrm{~g} /$ head/day microalgae; $\mathrm{P}$ - kept on pasture with $600 \mathrm{~g}$ concentrate; PMA - kept on pasture with $600 \mathrm{~g}$ concentrate with microalgae inclusion (15 g/head/day). The $\mathrm{C}$ and CMA groups were housed indoors, while the goats from $P$ and PMA groups were kept on a natural pasture. The experiment lasted 31 days, including the last 10 days of sampling period. Marine algae feeding had no negative effect on milk yield and milk composition. The microalgae inclusion considerably increased DHA concentration in milk in both marine algae groups $(0.40 \%$ in CMA and $0.39 \%$ in PMA), and additionally the $n-6 / n-3$ ratio was also more favourable in the microalgae supplemented groups (1.25 and 1.37 in CMA and PMA groups, respectively) as compared to the $C$ and $P$ groups respectively in which this ratio was 2.30 and $1.44(P<0.01)$. Also, marine algae supplementation increased the concentration of rumenic acid $(0.89 \%$ and $1.07 \%$ in $\mathrm{CMA}$ and PMA groups, respectively) in milk in comparison to $\mathrm{C}(0.46 \%)$ and $\mathrm{P}(0.77 \%)$ groups. So, it can be concluded that diet supplemented with microalgae significantly increased the concentration of beneficial fatty acids in goat milk.
\end{abstract}

\section{Introduction}

Nowadays, there has been increased interest in the modification of the fatty acid composition of milk and milk products by different feeding strategies. Composition of $n-3$ polyunsaturated fatty acids (PUFA) and rumenic acid (c9t11 C18:2) in milk, which could be improved by different way of feeding methods is the main concern. Increasing the supply of n-3 PUFA (such as grazing, oils, seeds or algae supplements) in the diet is one of the most essential ways of improving the bioactive composition of goat milk. Earlier reports showed that grazing considerably increased the rumenic acid and n-3 fatty acids contents in goat milk (Pajor et al., 2009; Delgadillo Puga et al., 2015). However, the most popular way to improve composition of foodstuffs by n-3 PUFA is supplementing animal diets with different plant oils, seeds, fish oil, freshwater and marine algae (Moate et al., 2013; Tsiplakou et al., 2017; Białek et al., 2018a). Moreover, fish oil and marine algae supplements in diets of ruminants are 
a good source of long chain PUFA (LC-PUFA), such as eicosapentaenoic acid (EPA) and docosahexaenoic acid (DHA) (Toral et al., 2017) that have beneficial effect for human health, including reduced risk of coronary heart disease (Li et al., 2003). Presently recommended EPA+DHA daily intake for adults is $250 \mathrm{mg}$ (EFSA Panel on Dietetic Products, Nutrition, and Allergies (NDA), 2010). However, previous studies reported that ruminant diet enriched with marine algae (e.g., Schizochytrium limacinum) resulted in decreased dry matter intake, milk yield and milk fat depression in dairy animals (Or-Rashid et al., 2008; Bichi et al., 2013). Schizochytrium limacinum is a well-known heterotrophic marine alga with widespread supplementing use, because of its high concentration of DHA (Ren et al., 2010). Nevertheless, data on feeding marine algae supplements are limited, particularly focused on dairy cows and ewes (Toral et al., 2010; Moran et al., 2017a,b). We hypothesized that goat milk fatty acid profile could be significantly improved when the animals are fed $15 \mathrm{~g} /$ head/day dried Schizochytrium limacinum marine algae, with no effect of feeding marine algae on milk fat content.

So, the aim of this study was to investigate the effect of the feeding of $15 \mathrm{~g} / \mathrm{head} /$ day marine algae on milk fatty acid composition of goats kept indoor and pasture.

\section{Material and methods}

\section{Experimental design}

The animal care was in accordance with the guidelines on the protection of animals used for scientific purposes (Directive 2010/63/EU of the European Parliament and of the Council). The study was carried out on a Hungarian native goat farm (Pest County, Hungary; geographical coordinates: $47^{\circ} 33^{\prime} 77.41^{\prime \prime} \mathrm{N} 19^{\circ} 37^{\prime} 26.11^{\prime \prime} \mathrm{E}$ ) (average annual temperature $12.3{ }^{\circ} \mathrm{C}$ with a total precipitation of $580 \mathrm{~mm}$ ). The animals were balanced for parity and time of kidding. The kidding started at the beginning of March. The weaning of the kids was carried out at the age of 8 weeks on average. After weaning, all goats were milked twice a day by machine milking. Forty multiparous Hungarian native goats (days in milk (DIM) 71) were randomly allocated to four treatment groups. The first and the second group were housed indoors, while the goats from other groups were kept on a natural pasture. The animals in the control group $(\mathrm{C}, \mathrm{n}=10)$ were fed $1500 \mathrm{~g}$ alfalfa hay and $600 \mathrm{~g}$ concentrate; in the second group (CMA, $n=10)$ goats received the same forages and concentrate with addition of $15 \mathrm{~g} / \mathrm{head} /$ day dried Schizochytrium limacinum marine algae. The does in the third group were kept all day long on pasture $(\mathrm{P}, \mathrm{n}=10)$ and were fed $600 \mathrm{~g}$ concentrate without microalgae supplementation. Finally, in the fourth group (PMA, $n=10$ ) goats were kept on pasture and fed additionally the same amount of concentrate with the addition of $15 \mathrm{~g} / \mathrm{head} /$ day dried microalgae. The dried microalgae supplement was produced by Alltech Inc. (ALL-G-RICH ${ }^{\circledR}$; Dunboyne, Co Meath, Ireland) and contained 30.19 and $58.72 \mathrm{~g} / 100 \mathrm{~g}$ of total fatty acids (FA) of DHA and palmitic acid, respectively. In each group, the concentrate was given individually twice a day in equal amounts during milking. A commercial trace-mineralized salt block and drinking water were provided free of choice to all animals.

The experiment lasted 31 days with the first 21 days of adaptation to the diet and the last 10 days of sampling. The control and the experimental concentrates were approximately isonitrogenous and balanced by energy content. The diets were adjusted to the National Research Council recommendations of energy and protein requirements for dairy goats (NRC, 2007). The composition of the experimental diets is shown in Table 1.

Utilization of native pasture is extensive in order to avoid over-grazing of the grassland. The main species were Festuca pseudovina, Cynodon dactylon, and the main legume was Lotus corniculatus. The annual grass yield (green) was 1.4 t/ha green yield. The stocking density of the pastures grazed by the goat was about $0.5 \mathrm{AU} / \mathrm{ha}$. Before starting the grazing, the grass yield was estimated by the clipping method using a $2 \mathrm{~m}^{2}$ frame. Five random samples were taken ( $3 \mathrm{~cm}$ above ground) from each plot. After grazing, herbage residuals were cut, weighted and yields were calculated as before. Consumed grass yield was calculated by the difference of the pre-grazing grass yield per $\mathrm{m}^{2}$ and the post-grazing grass yield per $\mathrm{m}^{2}$.

Milk samples were taken from each animal twice a day during 10 days of the experimental period at 06:00 and 18:00. Two milk samples were collected into $50 \mathrm{ml}$ plastic tubes from every goat (one tube for analysis of milk composition, other tube for determination of fatty acid composition), and the samples were immediately transported to the laboratory. Before laboratory investigation, morning and evening milk samples for each animal were combined for analysis of chemical composition. The milk samples for determination of milk 
Table 1. Chemical composition and fatty acid (FA) profile of forage

\begin{tabular}{|c|c|c|c|c|}
\hline \multirow{2}{*}{ Indices } & \multicolumn{2}{|l|}{ Indoor } & \multicolumn{2}{|l|}{ Pasture } \\
\hline & $\overline{\mathrm{C}^{1}}$ & $\mathrm{CMA}^{2}$ & $\overline{\mathrm{P}^{3}}$ & $\mathrm{PMA}^{4}$ \\
\hline \multicolumn{5}{|l|}{ Ingredients, $\%$} \\
\hline pasture & - & - & 74.34 & 74.33 \\
\hline alfalfa hay & 71.29 & 71.28 & - & - \\
\hline concentrate & 28.71 & 27.98 & 25.66 & 25.01 \\
\hline microalgae $e^{5,6}$ & - & 0.74 & - & 0.66 \\
\hline $\mathrm{DMl}^{7}, \mathrm{~kg} / \mathrm{day}$ & 1.89 & 1.89 & 2.12 & 2.12 \\
\hline \multicolumn{5}{|l|}{ Chemical composition } \\
\hline $\begin{array}{l}\text { dry matter (DM), g/kg } \\
\text { forage }\end{array}$ & 902 & 902 & 378 & 378 \\
\hline crude protein, g/kg DM & 188.70 & 189.00 & 154.00 & 154.27 \\
\hline crude fat, g/kg DM & 25.03 & 28.27 & 38.34 & 41.23 \\
\hline crude fibre, g/kg DM & 193.82 & 193.64 & 212.14 & 211.98 \\
\hline crude ash, g/kg DM & 65.62 & 65.78 & 68.78 & 68.92 \\
\hline $\mathrm{NE}_{1}^{8}, \mathrm{MJ} / \mathrm{kg} \mathrm{DM}$ & 6.44 & 6.44 & 6.13 & 6.13 \\
\hline \multicolumn{5}{|l|}{ Main FA, $\%$ of total FA } \\
\hline $\mathrm{C} 12: 0$ & 0.23 & 0.23 & 0.25 & 0.25 \\
\hline $\mathrm{C} 14: 0$ & 0.62 & 0.83 & 0.52 & 0.71 \\
\hline $\mathrm{C} 16: 0$ & 13.26 & 15.38 & 11.50 & 13.39 \\
\hline C18:0 & 2.82 & 2.81 & 1.93 & 1.92 \\
\hline C18:1n-9 & 30.70 & 31.96 & 37.61 & 38.74 \\
\hline C18:2n-6 & 29.97 & 24.66 & 27.78 & 23.03 \\
\hline C18:3n-3 & 16.85 & 17.08 & 14.50 & 14.71 \\
\hline $\mathrm{C} 22: 6 n-3(\mathrm{DHA})^{9}$ & - & 3.79 & - & 2.32 \\
\hline
\end{tabular}

${ }^{1} \mathrm{C}$ - control diet (hay and concentrate), ${ }^{2}$ CMA - control diet supplemented with $15 \mathrm{~g} /$ head/day microalgae, ${ }^{3} \mathrm{P}$ - pasture-based diet, ${ }^{4} \mathrm{PMA}$ - pasture-based diet supplemented with $15 \mathrm{~g} / \mathrm{head} / \mathrm{day}$ microalgae; ${ }^{5}$ microalgae chemical composition: DM $-929 \mathrm{~g} / 1000 \mathrm{~g}$, crude protein - $148 \mathrm{~g} / \mathrm{kg} \mathrm{DM}$, crude fat $-482 \mathrm{~g} / \mathrm{kg} \mathrm{DM}$, crude fibre $-23 \mathrm{~g} / \mathrm{kg} \mathrm{DM}$, ash $-38 \mathrm{~g} / \mathrm{kg} \mathrm{DM} ;{ }^{6}$ microalgae contained, $\mathrm{g} / 100 \mathrm{~g}$ FA: C12:0 0.14, C14:0 4.37, C16:0 58.72, C18:0 1.35, C18:1n-9 1.33, C18:2n-6 0.47, C18:3n-3 0.17, C22:6n-3 30.19, ${ }^{7} \mathrm{DMl}$ - dry matter intake; ${ }^{8} \mathrm{NE}_{\text {I }}$ - net energy; ${ }^{9} \mathrm{DHA}$ daily intake: $2027.8 \mathrm{mg}$

composition were stored at $4{ }^{\circ} \mathrm{C}$ for the latter analysis, the other milk samples were frozen and stored at $-20^{\circ} \mathrm{C}$ for the analysis of fatty acids.

\section{Chemical analysis}

The forage samples were analysed for dry matter, crude protein, crude fat, crude fibre and crude ash according to the procedure of the Hungarian Feed Codex (2004).

Fat, protein, lactose and total solids contents of milk were determined using a LactoScope ${ }^{\mathrm{TM}}$ analyser (Perten Instruments, Hägersten, Sweden). Milk fat was extracted with the method of Folch et al. (1957). Fatty acids were re-esterified to methyl esters using sodium methanol and boron trifluoride $\left(\mathrm{BF}_{3}\right)$ (Park and Goins, 1994). Methyl esters of FA were determined by gas chromatography (gas chromatographer GC 2010, Shimadzu, Kyoto, Japan) with a flame ionization detector (FID) and a column
(CP-SIL-88, $100 \mathrm{~m} \times 0.25 \mathrm{~mm} \times 0.2 \mu \mathrm{m})$. The split injection ratio was 50:1. Helium was used as the carrier gas, applying a flow rate of $28 \mathrm{~cm} / \mathrm{s}$. The injector and detector temperatures were 270 and $300{ }^{\circ} \mathrm{C}$, respectively. The oven temperature programmed run started at $80{ }^{\circ} \mathrm{C}$, then was increased $2.5^{\circ} \mathrm{C} / \mathrm{min}$ up to $205^{\circ} \mathrm{C}$ and held for $20 \mathrm{~min}$ and then increased again to $225{ }^{\circ} \mathrm{C}$ at $10{ }^{\circ} \mathrm{C} / \mathrm{min}$, and held for $5 \mathrm{~min}$. Peaks were identified on the basis of the retention times of standard methyl esters of individual FA (Mixture Me 100, Larodan Fine Chemicals AB, Limhamn, Sweden). The individual FA were calculated by the ratio of their peak area to the total area of all observed acids. The FA were quantitatively and qualitatively determined ( $\mathrm{mg} / 100 \mathrm{ml}$ and \% of total FA); in this study the results were presented as $\%$ of total FA. The selected FA combinations were calculated by using FA data: saturated fatty acids (SFA); monounsaturated fatty acids (MUFA); PUFA; total n-6 and n-3 PUFA and n-6:n-3 ratio.

DHA transfer from feed to milk efficiency was calculated according to Moate et al. (2013): DHA in milk yield (g/day) / DHA intake (g/day).

\section{Statistical analysis}

Statistical analysis, processed by the SPSS 23.0 software package (IBM Corporation, Armonk, NY, USA), was carried out in order to determine the effect of diets on milk composition and FA profile by the two different keeping treatments (indoor and pasture). The significance of differences was assessed by Student's t-test in case of normal distribution (Shapiro-Wilk's test). Since data were not normally distributed, variables were subjected to Mann-Whitney U test. Data were expressed as mean \pm SD. Differences are shown when $P<0.05$.

\section{Results}

The daily milk yield was similar among treatments at the start of the trial. During the study, dairy goat milk production was unaffected by marine algae supplementation. Average value of daily milk was $1.51 /$ day. The marine algae feeding caused higher $(P<0.05)$ fat $(3.93$ and $3.87 \mathrm{~g} / 100 \mathrm{~g})$ content as compared to milk from goats kept indoors or on pasture wthout marine algae supplementation (3.46 and $3.50 \mathrm{~g} / 100 \mathrm{~g}$, respectively) (Table 2). In contrast, only in grazing groups marine algae addition significantly influenced the milk protein and total solids non-fat content $(3.24$ and $8.66 \mathrm{~g} / 100 \mathrm{~g}$ in P group vs 2.94 and $8.28 \mathrm{~g} / 100 \mathrm{~g}$ in PMA group, respectively). 
Table 2. Chemical composition of goat milk from different keeping treatments (mean $\pm \mathrm{SD}$ ), \%

\begin{tabular}{lllll}
\hline \multirow{2}{*}{ Indices } & \multicolumn{3}{l}{ Indoor } & \multicolumn{3}{l}{ Pasture } \\
\cline { 2 - 3 } \cline { 5 - 6 } $\mathrm{C}^{1}$ & $\mathrm{CMA}^{2}$ & $\mathrm{P}^{3}$ & $\mathrm{PMA}^{4}$ \\
\hline Fat & $3.50 \pm 0.19^{\mathrm{a}}$ & $3.93 \pm 0.45^{\mathrm{b}}$ & $3.46 \pm 0.26^{\mathrm{a}}$ & $3.87 \pm 0.28^{\mathrm{b}}$ \\
Protein & $2.92 \pm 0.10$ & $2.93 \pm 0.08$ & $3.24 \pm 0.07^{\mathrm{b}}$ & $2.94 \pm 0.07^{\mathrm{a}}$ \\
Lactose & $4.70 \pm 0.08^{\mathrm{b}}$ & $4.66 \pm 0.02^{\mathrm{a}}$ & $4.72 \pm 0.04^{\mathrm{b}}$ & $4.64 \pm 0.03^{\mathrm{a}}$ \\
Total solids & $8.32 \pm 0.18$ & $8.29 \pm 0.10$ & $8.66 \pm 0.08^{\mathrm{b}}$ & $8.28 \pm 0.10^{\mathrm{a}}$ \\
non-fat & & & & \\
Total solids & $11.82 \pm 0.30$ & $12.22 \pm 0.50$ & $12.12 \pm 0.28$ & $12.15 \pm 0.36$ \\
\hline${ }^{1} \mathrm{C}-$ control diet (hay and concentrate), ${ }^{2} \mathrm{CMA}-$ control diet supple- \\
mented with 15 g/head/day microalgae, ${ }^{3} \mathrm{P}-$ pasture-based diet, \\
${ }^{4} \mathrm{PMA}$ - pasture-based diet supplemented with 15 g/head/day microal- \\
gae; ab - means with different superscripts within each row separately \\
for indoor and pasture are significantly different at $P<0.05$
\end{tabular}

The enrichment of experimental diets with marine algae significantly influenced the FA profile of milk fat (Table 3). The marine algae supplementation increased the concentrations of caprylic acid (C8:0) (but only in goats kept on pasture), capric acid (C10:0), lauric acid
(C12:0), myristic acid (C14:0), palmitic acid (C16:0), vaccenic acid (t11 C18:1), docosahexaenoic acid (C22:6), total n-3 PUFA and rumenic acid (c9t11 C18:2), while significantly decreased the concentrations of stearic acid (18:0), oleic acid (c11 C18:1) and linoleic (C18:2) (but only in indoor kept goats) in goat milk.

The n-6/n-3 ratio was more favourable (lower) in CMA and PMA groups (1.25 and 1.37, respectively) in comparison to $\mathrm{C}$ (2.30) and $\mathrm{P}$ (1.44) groups, respectively.

Based on fat and DHA content of milk in CMA and PMA groups (3.93 and $0.40 \%$ vs 3.87 and $0.39 \%$, respectively), daily $15 \mathrm{~g} /$ head marine algae supplementation resulted in 15.7 and $15.1 \mathrm{mg}$ DHA content in $100 \mathrm{mg}$ of milk in CMA and PMA treatments, respectively (Table 4). Moreover, the DHA conversion efficiency ratio from marine algae fodder to milk was 11.6 and $11.2 \%$ in CMA and PMA group, respectively.

Table 3. Effect of marine algae supplementation on fatty acid (FA) profile of goat milk (mean $\pm S D$ ), $\%$ of total FA (except n-6/n-3 ratio)

\begin{tabular}{|c|c|c|c|c|}
\hline \multirow{2}{*}{ Fatty acids } & \multicolumn{2}{|l|}{ Indoor } & \multicolumn{2}{|l|}{ Pasture } \\
\hline & $\overline{\mathrm{C}^{1}}$ & $\mathrm{CMA}^{2}$ & $\overline{\mathrm{P}^{3}}$ & $\mathrm{PMA}^{4}$ \\
\hline C6:0 & $0.11 \pm 0.05$ & $0.15 \pm 0.11$ & $0.11 \pm 0.05$ & $0.15 \pm 0.11$ \\
\hline C8:0 & $1.08 \pm 0.18$ & $1.27 \pm 0.26$ & $1.06 \pm 0.25^{\mathrm{a}}$ & $1.54 \pm 0.29^{b}$ \\
\hline C10:0 & $6.09 \pm 0.58^{a}$ & $8.27 \pm 0.64^{b}$ & $6.90 \pm 1.71^{\mathrm{a}}$ & $10.00 \pm 0.81^{b}$ \\
\hline C12:0 & $3.04 \pm 0.34^{\mathrm{a}}$ & $3.89 \pm 0.27^{b}$ & $4.13 \pm 0.94^{\mathrm{a}}$ & $4.66 \pm 0.49^{b}$ \\
\hline C14:0 & $9.72 \pm 0.66^{\mathrm{a}}$ & $12.51 \pm 0.40^{\mathrm{b}}$ & $10.41 \pm 1.18^{a}$ & $11.97 \pm 0.57^{b}$ \\
\hline C14:1 & $0.09 \pm 0.01^{\mathrm{a}}$ & $0.13 \pm 0.02^{b}$ & $0.14 \pm 0.04^{\mathrm{a}}$ & $0.15 \pm 0.03^{b}$ \\
\hline C16:0 & $32.24 \pm 1.54^{\mathrm{a}}$ & $39.59 \pm 1.74^{b}$ & $34.49 \pm 1.73^{\mathrm{a}}$ & $37.16 \pm 1.21^{b}$ \\
\hline C16:1 & $0.57 \pm 0.02^{a}$ & $0.69 \pm 0.04^{b}$ & $0.76 \pm 0.05$ & $0.75 \pm 0.05$ \\
\hline C18:0 & $13.59 \pm 1.16^{b}$ & $7.64 \pm 1.03^{\mathrm{a}}$ & $10.78 \pm 1.62^{b}$ & $7.78 \pm 1.11^{\mathrm{a}}$ \\
\hline c11 C18:1n-9 & $24.77 \pm 1.95^{b}$ & $17.29 \pm 1.33^{a}$ & $22.53 \pm 3.04^{b}$ & $16.30 \pm 1.40^{\mathrm{a}}$ \\
\hline t11 C18:1n-7 & $1.38 \pm 0.23^{a}$ & $1.72 \pm 0.23^{b}$ & $1.69 \pm 0.34^{a}$ & $2.24 \pm 0.71^{b}$ \\
\hline C18:2n-6 & $2.49 \pm 0.15^{b}$ & $1.78 \pm 0.17^{a}$ & $1.98 \pm 0.27$ & $2.00 \pm 0.14$ \\
\hline C18:3n-3 & $0.71 \pm 0.08$ & $0.59 \pm 0.13$ & $0.71 \pm 0.13$ & $0.67 \pm 0.12$ \\
\hline$C 20: 3 n-6$ & $0.03 \pm 0.01$ & $0.03 \pm 0.01$ & $0.03 \pm 0.01^{b}$ & $0.02 \pm 0.01^{\mathrm{a}}$ \\
\hline C20:4n-6 & $0.17 \pm 0.02^{\mathrm{a}}$ & $0.18 \pm 0.01^{b}$ & $0.19 \pm 0.02^{b}$ & $0.16 \pm 0.02^{a}$ \\
\hline C20:5n-3 (EPA) & $0.05 \pm 0.01$ & $0.06 \pm 0.01$ & $0.07 \pm 0.04$ & $0.06 \pm 0.01$ \\
\hline$C 22: 5 n-3$ & $0.13 \pm 0.02^{b}$ & $0.08 \pm 0.02^{\mathrm{a}}$ & $0.17 \pm 0.02^{b}$ & $0.10 \pm 0.01^{a}$ \\
\hline $\mathrm{C} 22: 6 n-3(\mathrm{DHA})$ & $0.00 \pm 0.00^{\mathrm{a}}$ & $0.40 \pm 0.06^{b}$ & $0.07 \pm 0.01^{\mathrm{a}}$ & $0.39 \pm 0.07^{b}$ \\
\hline odd FA & $2.54 \pm 0.10^{a}$ & $2.37 \pm 0.17^{b}$ & $2.26 \pm 0.12$ & $2.22 \pm 0.11$ \\
\hline SFA & $69.12 \pm 1.91^{\mathrm{a}}$ & $76.14 \pm 1.74^{b}$ & $70.85 \pm 3.59^{a}$ & $76.06 \pm 1.66^{b}$ \\
\hline MUFA & $26.85 \pm 1.80^{b}$ & $19.86 \pm 1.52^{\mathrm{a}}$ & $25.16 \pm 3.28^{b}$ & $19.46 \pm 1.60^{\mathrm{a}}$ \\
\hline PUFA & $4.04 \pm 0.19$ & $4.00 \pm 0.36$ & $4.00 \pm 0.50^{\mathrm{a}}$ & $4.48 \pm 0.42^{b}$ \\
\hline$n-6$ & $2.69 \pm 0.16^{b}$ & $1.98 \pm 0.18^{\mathrm{a}}$ & $2.20 \pm 0.29$ & $2.18 \pm 0.15$ \\
\hline$n-3$ & $0.89 \pm 0.09^{a}$ & $1.13 \pm 0.14^{b}$ & $1.02 \pm 0.12^{\mathrm{a}}$ & $1.22 \pm 1.12^{b}$ \\
\hline n-6/n-3 ratio & $2.30 \pm 0.28^{b}$ & $1.25 \pm 0.13^{\mathrm{a}}$ & $1.44 \pm 0.19^{b}$ & $1.37 \pm 0.15^{a}$ \\
\hline c9t11 C18:2 (rumenic acid) & $0.46 \pm 0.07^{\mathrm{a}}$ & $0.89 \pm 0.08^{b}$ & $0.77 \pm 0.12^{\mathrm{a}}$ & $1.07 \pm 0.21^{b}$ \\
\hline
\end{tabular}

${ }^{1} \mathrm{C}$ - control diet (hay and concentrate), ${ }^{2} \mathrm{CMA}$ - control diet supplemented with $15 \mathrm{~g} / \mathrm{head} / \mathrm{day}$ microalgae, ${ }^{3} \mathrm{P}-$ pasture-based diet, ${ }^{4}$ PMA - pasture-based diet supplemented with $15 \mathrm{~g} / \mathrm{head} /$ day microalgae; SFA - saturated fatty acids; MUFA - monounsaturated fatty acids; PUFA - polyunsaturated fatty acids, odd FA - odd-chain fatty acids; ${ }^{\text {ab }}$ - means with different superscripts within each row separately for indoor and pasture are significantly different at $P<0.05$ 
Table 4. Calculated docosahexaenoic acid (DHA) conversation efficiency from diet to milk

\begin{tabular}{|c|c|c|c|c|c|}
\hline Treatment & $\begin{array}{l}\text { Daily } \\
\text { intake of } \\
\text { DHA g/day }\end{array}$ & $\begin{array}{l}\text { Average } \\
\text { milk DHA } \\
\text { content, } \\
\text { mg/100 g } \\
\text { milk }\end{array}$ & $\begin{array}{l}\text { Milk } \\
\text { production, I }\end{array}$ & $\begin{array}{l}\text { DHA in } \\
\text { milk yield, } \\
\text { g/day }\end{array}$ & $\begin{array}{l}\text { DHA } \\
\text { efficiency } \\
\text { ratio, \% }\end{array}$ \\
\hline $\mathrm{CMA}^{1}$ & 2.028 & 15.7 & 1.5 & 0.236 & 11.6 \\
\hline $\mathrm{PMA}^{2}$ & 2.028 & 15.1 & 1.5 & 0.226 & 11.2 \\
\hline
\end{tabular}

${ }^{1} \mathrm{CMA}$ - control diet supplemented with $15 \mathrm{~g} /$ head/day microalgae, ${ }^{2}$ PMA - pasture-based diet supplemented with $15 \mathrm{~g} / \mathrm{head} / \mathrm{day}$ microalgae

\section{Discussion}

Daily milk yield did not differ among feeding treatments. Lack of significance in this trait may be due to the low amount of supplemented marine algae (15 g/head/day). Milk fat and protein contents were consistent with previous study (Kuchtík et al., 2015). Supplementation of marine algae in indoor group had no effect on the milk protein content as in previous reports (Franklin et al., 1999). However, decreased protein content was measured in the pastured animals. The goats in the algal groups had lower lactose content. Also total solid non-fat was different between groups but only in pasture kept animals. Total solids did not show any differences. Pajor et al. (2009) reported that the grazing slightly increased the milk protein and solids non-fat content of goat milk. The milk protein content is crucial not only for consumers but also for farmers and milk processors, because it has a great influence on cheese composition. Papadopoulos et al. (2002) reported that ewe milk fat and protein contents were significantly increased by treatment containing marine algae at doses: $23.5,47$ and $94 \mathrm{~g}$ /day/animal. The same positive effect was also found by Póti et al. (2015) with freshwater algae supplementation (10 g/kg DM intake) and by Reynolds et al. (2006), where ewe milk fat content was higher for soybean and marine algal oil supplementation (2:1 ratio w/w; $30 \mathrm{~g} / \mathrm{kg} \mathrm{DM}$ ). In contrary, Boeckaert et al. (2008) reported that algae supplementation level of about $10 \mathrm{~g} / \mathrm{kg}$ DM intake significantly reduced the cow milk fat content. In addition, Bichi et al. (2013) found milk fat depression in dairy ewes fed algae containing fodder ( $8 \mathrm{~g} / \mathrm{kg}$ of DM).

The fish oil and marine algae supplements in diets of ruminants are definitely good source of LCPUFA, such as DHA. It was reported that these fatty acid affect the biohydrogenation of C18:2n-6 and C18:3n-3 fatty acids in the rumen. LC-PUFA inhibit the step of hydrogenation from trans $\mathrm{C} 18: 1$ to $\mathrm{C} 18: 0$ causing higher level of trans C18:1 fatty acids, and other specific biohydrogenation intermediates have been associated with milk fat depression and negatively influenced protozoa and cellulolytic bacteria inhabiting in rumen (Toral et al., 2017; Białek et al., 2018b). In the present study, the effect of $15 \mathrm{~g} / \mathrm{head} /$ day marine algae supplementation on rumen viability and fermentation was not so unequivocal; marine algae feeding elevated fat content of milk and concentrations of small and medium chained fatty acids (e.g., C8:0 and C10:0) of milk. On the contrary, the odd chain fatty acids (OCFAs) concentrations were slightly decreased in the milk of the experimental goats supplemented with marine algae in comparison to milk from control animals. The OCFAs are also an indicator of ruminal fermentation, produced by ruminal bacterial populations. Nevertheless, the effect of marine algae supplementation on animal health parameters have been poorly studied.

The short and medium chain fatty acids are hydrolysed rapidly and absorbed directly by the liver via portal vein, thereby these fatty acids have been used for patients with malabsorption syndrome (Papamandjaris et al., 1998). The marine algae supplementation resulted in significantly higher C8:0 and C10:0 fatty acids. The short and medium-chain fatty acids become more and more interesting for nutritionists. Recently, Gómez-Cortés et al. (2018) summarized the milk fatty acids and their potential health benefits in a review report, and stated that short and medium-chain fatty acids help to maintain the gut microbiota and body weight control.

Concentration of the DHA, which is required for many metabolic processes and effectively prevent coronary heart disease (CHD) in humans was increased by the experimental diet. Additionally, the DHA is one of the most valuable health promoting components. In the present study, the DHA values were markedly higher due to marine algae supplementation regardless animal husbandry system. Also Toral et al. (2010) found that feeding marine algae supplementations considerably increased the DHA content in milk. In the present study, the average values of DHA transfer efficiency in PMA and CMA treatments were 11.2 and $11.6 \%$, respectively. Previously, Moran et al. (2017a) found that DHA concentration and conservation efficiency from algae to milk dramatically raised up to $20 \%$ during 21 days, then reached the plateau (between 21-22\%) 7 days later. In contrast, Moran et al. (2017b) found higher average efficiencies ratio ( 7 and 18\%) in dairy cows fed Aurantiochytrium limacinum enriched 
fodder (105 or $146 \mathrm{~g} /$ day/cow) during the 12 -week treatment. Other study reported that transfer efficiency was 8.9 in cows fed 125-375 g/day marine algae (Moate et al., 2013). However, the transfer efficiency ratio of DHA from fish oil contains diet to milk was less than 5\% in cows (Palmquist, 2009). These results suggest that the biohydrogenation level of DHA in Schizochytrium limacinum algal meal in the rumen is less than other type of n-3 fatty acid supplements. This may be related to the structure of Schizochytrium limacinum cell membrane (Moran et al., 2017a). The authors speculated that algal cell membrane protects the DHA contents during drying processing. The DHA transfer efficiency from diet to milk is influenced by fat protection against biohydrogenation. Franklin et al. (1999) found that the DHA transfer efficiency ratio of dairy cows fed Schizochytrium limacinum marine algae coated by xylose was higher $(16.7 \%)$ than in animals fed by uncoated (unprotected) marine algae (8.4\%). However, in this study, the experimental period was relatively short, but some reports stated that DHA fatty acid concentration and the transfer coefficient for DHA have changed markedly within 21-28 days and remained relatively constant during observation period on different marine algae diets (Franklin et al., 1999; Moate et al., 2013; Moran et al., 2017a,b). Nevertheless, further research need to determine the long-term effect of marine algae supplementation on DHA concentration in milk and DHA transfer efficiency from marine algae diet to milk.

Other valuable fatty acid is eicosapentaenoic acid (EPA; C20:5n-3). Daily supplementation of goats with $15 \mathrm{~g}$ marine algae per animal under this trial resulted in 2.36 and $2.32 \mathrm{mg}$ EPA per $100 \mathrm{ml}$ of milk, and 15.7 and $15.1 \mathrm{mg}$ DHA per $100 \mathrm{ml}$ of milk in CMA and PMA groups, respectively. Therefore, the sum of EPA+DHA value was $18.1 \mathrm{mg} / 100 \mathrm{ml}$ in marine algae enriched diet (CMA) and $17.4 \mathrm{mg} / 100 \mathrm{ml}$ in grazing with marine algae treatment (PMA). The recommended intake of EPA+DHA is $250 \mathrm{mg}$ for adults and $100 \mathrm{mg}$ for infants (EFSA Panel on Dietetic Products, Nutrition, and Allergies (NDA), 2010). Currently, the average EPA+DHA intake for humans is estimated at $88.1 \mathrm{mg} /$ day (together with foods and dietary supplements) (Zhang et al., 2018). The difference between the recommended and average intake of EPA+DHA (161.9 mg/day) is equivalent to 895 and $930 \mathrm{ml}$ of milk obtained from the marine algae supplemented goats from CMA and PMA groups, respectively.

In the present study, the n-6/n-3 ratios dramatically decreased in Schizochytrium limacinum marine algae enriched groups. This is in concordance with other reports. Toral et al. (2010) found that feeding lipid supplementations considerably decreased the $\mathrm{n}-6 / \mathrm{n}-3$ ratio in milk. The $\mathrm{n}-6 / \mathrm{n}-3$ ratio is generally used to assess the nutritional value of fats. The low n-6/n-3 ratio in the milk of animals that received microalgae is in line with the new recommendations for human nutrition (EFSA Panel on Dietetic Products, Nutrition, and Allergies (NDA), 2010).

The content of C18:0 fatty acid was significantly lower in the PMA and CMA treatments. According to partial biohydrogenation, the polyunsaturated fatty acids, such as linoleic acid, are biohydrogenated to $\mathrm{C} 18: 0$ and various isomers of $\mathrm{C} 18: 1$ in the rumen. In contrast, LC-PUFA n-3 in the diet inhibit vaccenic acid saturation in the rumen (Or-Rashid et al., 2008). As a consequence, the feeding of $n-3$ fatty acids increased markedly the vaccenic acid content and parallel decreased the proportion of C18:0 in milk fat. The reducing availability of C18:0 exerts influence on the oleic acid (c11 C18:1) concentration in milk. Oleic acid is mainly performed by stearoylCoA desaturase (SCD) enzyme in mammary gland. Shingfield et al. (2010) reported that SCD enzyme was responsible for $60 \%$ of amount of oleic acid synthesis in milk; while other part was absorbed by intestinal wall in digestive tract.

The microalgae supplementation have significant effect on the concentration of rumenic acid in milk. The rumenic acid concentration was the most favourable in pasture and marine algae combined diet. Throughout biohydrogenation, rumenic acid is formed from linoleic acid in the rumen by anaerobic bacteria (such as Butyrivibrio fibrisolvens), with vaccenic acid ( $t 11 \mathrm{C} 18: 1)$ as intermediates. The water content of the grass affects microbiological fermentation and $\mathrm{pH}$ in the rumen. It has been shown that grazing with algae combined diet markedly improved the rumen environment for bacteria, such as B. fibrisolvens. This is in concordance with previous report where favourable $\mathrm{pH}$ (6.0 or above) had a positive effect on vaccenic acid and conjugated linoleic acid (CLA) isomer production (Tsiplakou et al., 2006). The vaccenic acid is converted to rumenic acid by $\Delta^{9}$-desaturase in the mammary gland and also in some human tissues (Kuhnt et al., 2006). The rumenic acid suppresses carcinogenesis, modulates the immune system, and reduces atherogenesis (Lock et al., 2009).

The milk composition determines the composition of cheese. Results of this report suggested that the cheese produced from bioactive compounds enriched milk could have higher nutritional value. 
It is confirmed by Luna et al. (2007), who reported that the cheese processing did not change the fatty acid concentrations, which mainly depended on content of biologically active components of milk.

\section{Conclusions}

Daily $15 \mathrm{~g} / \mathrm{head}$ Schizochytrium limacinum marine algae supplementation improved the fatty acid content of goat milk without any negative effect on milk yield and fat content regardless animal husbandry system. In goats fed concentrate with marine algae supplementation significantly higher levels of rumenic acid and n-3 polyunsaturated fatty acids (such as docosahexaenoic acid) in milk were observed. Supplementation with marine algae is suitable for improving the content of bioactive compounds in goat milk, which is important for consumers (from the point of view of dietary benefits).

\section{Acknowledgements}

This work is supported by the EFOP-3.6.3VEKOP-16-2017-00008 project. The project is cofinanced by the European Union and the European Social Fund.

\section{References}

Białek A., Białek M., Lepionka T., Kaszperuk K., Banaszkiewicz T., Tokarz A., 2018a. The effect of pomegranate seed oil and grapeseed oil on cis-9, trans-11 CLA (rumenic acid), n-3 and n-6 fatty acids deposition in selected tissues of chickens. J. Anim. Physiol. Anim. Nutr. 102, 962-976, https://doi.org/10.1111/ jpn.12902

Białek M., Czauderna M., Białek A., 2018b. Partial replacement of rapeseed oil with fish oil, and dietary antioxidants supplementation affects concentrations of biohydrogenation products and conjugated fatty acids in rumen and selected lamb tissues. Anim. Feed Sci. Technol. 241, 63-74, https://doi. org/10.1016/j.anifeedsci.2018.04.015

Bichi E., Hervás G., Toral P.G., Loor J.J., Frutos P., 2013. Milk fat depression induced by dietary marine algae in dairy ewes: Persistency of milk fatty acid composition and animal performance responses. J. Dairy Sci. 96, 524-532, https://doi. org/10.3168/jds.2012-5875

Boeckaert C., Vlaeminck B., Dijkstra J., Issa-Zacharia A., Van Nespen T., Van Straalen W., Fievez V., 2008. Effect of dietary starch or micro algae supplementation on rumen fermentation and milk fatty acid composition of dairy cows. J. Dairy Sci. 91, 4714-4727, https://doi.org/10.3168/jds.2008-1178

Delgadillo Puga C., Castillo Domínguez R.M., Cuchillo Hilario M., Díaz Martínez M., Montaño Benavidez S., 2015. Radical scavenging activity and health and risk fatty acid indices of soft goats' milk cheeses. Arch. Latinoam. Prod. Anim. 23, 21-26

Directive 2010/63/EU of the European Parliament and of the Council of 22 September 2010 on the protection of animals used for scientific purposes. Off. J. EU L 276, 33-79
EFSA Panel on Dietetic Products, Nutrition, and Allergies (NDA), 2010. Scientific Opinion on Dietary Reference Values for fats, including saturated fatty acids, polyunsaturated fatty acids, monounsaturated fatty acids, trans fatty acids, and cholesterol. EFSA J. 8, 1461, https://doi.org/10.2903/j. efsa.2010.1461

Franklin S.T., Martin K.R., Baer R.J., Schingoethe D.J., Hippen A.R., 1999. Dietary marine algae (Schizochytrium sp.) increases concentrations of conjugated linoleic, docosahexaenoic and transvaccenic acids in milk of dairy cows. J. Nutr. 129, 20482054, https://doi.org/10.1093/jn/129.11.2048

Folch J.M., Lees M., Sloane-Stanley G.H., 1957. A simple method for the isolation and purification of total lipids from animal tissues. J. Biol. Chem. 226, 495-509

Gómez-Cortés P., Juárez M., de La Fuente M.A., 2018. Milk fatty acids and potential health benefits: An updated vision. Trends Food Sci. Technol. 81, 1-9, https://doi.org/10.1016/j. tifs.2018.08.014

Hungarian Feed Codex. Volume 3, 2004. Laboratory methods and operations (in Hungarian). National Institute for Agricultural Quality Control. Budapest (Hungary)

Kuchtík J., Králičková S., Zapletal D., Węglarzy K., Šustová K., Skrzyżala I., 2015. Changes in physico-chemical characteristics, somatic cell count and fatty acid profile of Brown Short-haired goat milk during lactation. Anim. Sci. Pap. Rep. 33, 71-83

Kuhnt K., Kraft J., Moeckel P., Jahreis G., 2006. Trans-11-18: 1 is effectively 89 -desaturated compared with Trans-12-18: 1 in humans. Brit. J. Nutr. 95, 752-761, https://doi.org/10.1079/ BJN20051680

Li D., Bode O., Drummond H., Sinclair A.J., 2003. Omega-3 (n-3) fatty acids. In: F.D. Gunstone (Editor). Lipids for Functional Foods and Nutraceuticals. Oily Press, Bridgwater (UK), pp. 225-262, https://doi.org/10.1533/9780857097965.225

Lock A.L., Kraft J., Rice B.H., Bauman D.E., 2009. Biosynthesis and biological activity of rumenic acid: a natural CLA isomer. In: F. Destaillats, J.-L. Sébédio, F. Dionisi, J.-M. Chardigny (Editors). Trans Fatty Acids in Human Nutrition. Oily Press, Bridgwater (UK), pp. 195-230, https:// doi.org/10.1533/9780857097873.195

Luna P., Juárez M., de La Fuente M.A., 2007. Conjugated linoleic acid content and isomer distribution during ripening in three varieties of cheeses protected with designation of origin. Food Chem. 103, 1465-1472, https://doi.org/10.1016/j. foodchem.2006.10.062

Moate P.J., Williams S.R.O., Hannah M.C., Eckard R.J., Auldist M.J., Ribaux B.E., Jacobs J.L., Wales W.J., 2013. Effects of feeding algal meal high in docosahexaenoic acid on feed intake, milk production, and methane emissions in dairy cows. J. Dairy Sci. 96, 3177-3188, https://doi.org/10.3168/jds.2012-6168

Moran C.A., Morlacchini M., Fusconi G., 2017a. Enhancing the DHA content in milk from dairy cows by feeding ALL-G-RICH ${ }^{\mathrm{TM}}$. J. Appl. Anim. Nutr. 5, e11, https://doi.org/10.1017/jan.2017.9

Moran C.A., Morlacchini M., Keegan J.D., Fusconi G., 2017b. The effect of dietary supplementation with Aurantiochytrium limacinum on lactating dairy cows in terms of animal health, productivity and milk composition. J. Anim. Physiol. Anim. Nutr. 1-15, https://doi.org/10.1111/jpn.12827

NRC (National Research Council), 2007. Nutrient Requirements of Small Ruminants: Sheep, Goats, Cervids, and New World Camelids. The National Academies Press. Washington, DC (USA), https://doi.org/10.17226/11654 
Or-Rashid M.M., Kramer J.K.G., Wood M.A., McBride B.W., 2008. Supplemental algal meal alters the ruminal trans-18:1 fatty acid and conjugated linoleic acid composition in cattle. J. Anim. Sci. 86, 187-196, https://doi.org/10.2527/jas.20070085

Pajor F., Galló O., Steiber O., Tasi J., Póti P., 2009. The effect of grazing on the composition of conjugated linoleic isomers and other fatty acids of milk and cheese in goats. J. Anim. Feed Sci. 18, 429-439, https://doi.org/10.22358/jafs/66418/2009

Palmquist D.L., 2009. Omega-3 fatty acids in metabolism, health and nutrition and for modified animal product foods. Prof. Anim. Sci. 25, 207-249, https://doi.org/10.15232/S1080-7446(15)30713-0

Papadopoulos G., Goulas C., Apostolaki E., Abril R., 2002. Effects of dietary supplements of algae, containing polyunsaturated fatty acids, on milk yield and the composition of milk products in dairy ewes. J. Dairy Sci. 69, 357-365, https://doi.org/10.1017/ S0022029902005599

Papamandjaris A.A., Macdougall D.E., Jones P.J.H., 1998. Medium chain fatty acid metabolism and energy expenditure: Obesity treatment implications. Life Sci. 62, 1203-1215, https://doi. org/10.1016/S0024-3205(97)01143-0

Park P.W., Goins R.E., 1994. In situ preparation of fatty acid methyl esters for analysis of fatty acid composition in foods. J. Food Sci. 59, 1262-1266, https://doi.org/10.1111/j.1365-2621.1994. tb14691.x

Póti P., Pajor F., Bodnár A., Penksza K., Köles P., 2015. Effect of micro-alga supplementation on goat and cow milk fatty acid composition. Chilean J. Agric. Res. 75, 259-263, https://doi. org/10.4067/S0718-58392015000200017

Ren L.-J., Ji X.-J., Huang H., Qu L., Feng Y., Tong Q.-Q., Ouyang P.-K., 2010. Development of a stepwise aeration control strategy for efficient docosahexaenoic acid production by Schizochytrium sp. Appl. Microbiol. Biotech. 87, 1649-1656, https://doi. org/10.1007/s00253-010-2639-7
Reynolds C.K., Cannon V.L., Loerch S.C., 2006. Effects of forage source and supplementation with soybean and marine algal oil on milk fatty acid composition of ewes. Anim. Feed Sci. Technol. 131, 333-357, https://doi.org/10.1016/j.anifeedsci.2006.06.015

Shingfield K.J., Bernard L., Leroux C., Chilliard Y., 2010. Role of trans fatty acids in the nutritional regulation of mammary lipogenesis in ruminants. Animal 4, 1140-1166, https://doi.org/10.1017/ S1751731110000510

Toral P.G., Hervás G., Gómez-Cortés P., Frutos P., Juárez M., de La Fuente M.A., 2010. Milk fatty acid profile and dairy sheep performance in response to diet supplementation with sunflower oil plus incremental levels of marine algae. J. Dairy Sci. 93, 1655-1667, https://doi.org/10.3168/jds.2009-2769

Toral P.G., Hervás G., Carreño D., Leskinen H., Belenguer A., Shingfield J.K., Frutos P., 2017. In vitro response to EPA, DPA, and DHA: Comparison of effects on ruminal fermentation and biohydrogenation of 18-carbon fatty acids in cows and ewes. J. Dairy Sci.100, 6187-6198, https://doi.org/10.3168/jds.201712638

Tsiplakou E., Mountzouris K.C., Zervas G., 2006. Concentration of conjugated linoleic acid in grazing sheep and goat milk fat. Livest. Sci. 103, 74-84, https://doi.org/10.1016/j.livsci.2006.01.010

Tsiplakou E., Abdullah M.A.M., Alexandros M., Chatzikonstantinou M., Skliros D., Sotirakoglou K., Flemetakis E., Labrou N.E., Zervas G., 2017. The effect of dietary Chlorella pyrenoidosa inclusion on goats milk chemical composition, fatty acids profile and enzymes activities related to oxidation. Livest. Sci.197, 106-111, https://doi.org/10.1016/j.livsci.2017.01.014

Zhang Z., Fulgoni V.L., Kris-Etherton P.M., Mitmesser S.H., 2018. Dietary intakes of EPA and DHA Omega-3 fatty acids among US childbearing-age and pregnant women: an analysis of NHANES 2001-2014. Nutrients 10, 416, https://doi. org/10.3390/nu10040416 